\title{
Morphological Changes of Pancreatic B Cells in Ventromedial Hypothalamic (VMH)-lesioned Obese Rats
}

\author{
Yohei MIYAMOTO, Hajime MIYAMOTO, and Eimei SATO \\ Department of Animal Science, Faculty of Agriculture, Kyoto University, \\ Kitashirakawa, Sakyo-ku, Kyoto-shi, Kyoto 606, Japan
}

(Received 2 May 1989/Accepted 9 June 1989)

\begin{abstract}
Morphological changes of pancreatic B cells were investigated in ventromedial hypothalamic (VMH)-lesioned obese rats. An increase in body weight, a decrease in body length, and a marked increase in fat-pad were observed in $\mathrm{VMH}$-lesioned obese rats. The volume density of pancreatic islets and that of $\mathrm{B}$ cells in $\mathrm{VMH}^{-}$ lesioned obese rats were more increased than those in sham-operated control rats. The B cells of VMH-lesioned obese rats often showed a slight reaction for aldehyde fuchsin or anti-pig insulin serum. By the electron microscopy, the degranulated B cells were found to contain well developed Golgi apparatus and rough endoplasmic reticulum. These obsevations indicate increased activities of synthesis and release of insulin. We concluded that VMH-lesioned obesity was caused by accelerated lipogenesis with hypersecretion of insulin.
\end{abstract}

\section{視床下部腹内側核破壊肥満ラットに拈ける 膵島 $\mathrm{B}$ 細胞の形態学的変化}

\author{
宮本庸平・宮本 元・佐藤英明
}

京都大学農学部畜産学科

視床下部腹内側核 (ventromedial hypothalamus $: \mathrm{VMH}$ ) 破壊肥満ラットは肥満モデル動物の一つとし て有用とされており, 過食 [1], 血中インスリン值の上 昇（高インスリン血症） [2,3], 血中グルカゴン值 [4] および成長ホルモン值 [5] の低下などが認められてい る。なかでも, 高インスリン血症は肥満の成因的意義を もつものと考えられている [3]。インスリンを分泌する のは膵島の大部分を占める $\mathrm{B}$ 細胞であり, $\mathrm{VMH}$ 破壊肥 満ラットにおいても個々の膵島の肥大 [6-9] や B 細胞 の超微形態学的変化 [9]について報告されているが， 膵島 $\mathrm{B}$ 細胞の体積比率や免疫組織化学的特性については まだ明らかにされていない。

本実験では VMH 破壊肥満ラットの猝島 B 細胞につ いて, 形態計測的方法, 免疫組織化学的方法および電子 顕微鏡的方法を用いてより詳細な検討を行なった。

\section{材料および方法}

1. VMH 破壊手術 : 当研究室で維持している26-7 日齢の Wistar 系雌ラット40匹を用い, 手術は安岡 [10] や石橋ら [8] の方法に従って行なった。すなわち脳定 位固定装置（高橋商店製）によりラットを保定し, 間脳 細胞破壊装置（高橋商店製）により $3 \mathrm{~mA}$ の電流を 5 秒 間, 3 回通電し電気的に左右両側の VMH を破壊した。 術後, 感染予防のためペニシリン懸濁夜を投与した。対 照として，同領域に電極針を刺入するのみで電流を流さ ない疑似手術を施したものを 4 匹用いた。実験に供した ラットは光周期 $(13 \mathrm{~L}-11 \mathrm{D})$ および温度 $\left(21^{-2} 3^{\circ} \mathrm{C}\right)$ の 調節された飼育室で、ラット・マウス用固型飼料 NMF （オリエンタル酵母工業製）と水道水を自由に摂取させ た。食䬣摄取の行動観察や体重の測定を毎週 2 回行な

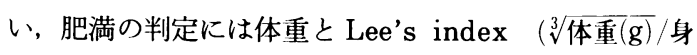


長 $(\mathrm{cm}))$ [11] を用いた。

2. 光学顕销鏡的方法: ラットは 90 日龄で sodiumpentobarbital 麻酔後，体重，体長などを測定したの ち，断頭屠殺し直ちに膵臓を摘出した。膵蔵はブアン液 で固定後，無作為に6個の組織片に分け，パラフィン包 埋を行ない， $5 \mu \mathrm{m}$ の連続切片を作製した。切片にはア ルデヒド・フクシン (AF)ーマッソン・ゴールドナー (MG) 染色 [12] を行なった。標本は2 種類の接眼ミクロメー ター $(10 \mathrm{~mm} \times 10 \mathrm{~mm}, 1$ 目 $1 \mathrm{~mm} ; 10 \mathrm{~mm} \times 10 \mathrm{~mm}, 1$ 目 $0.5 \mathrm{~mm}$ )を用い，当的法 $[12,13]$ により膵島（1 目 $1 \mathrm{~mm}$ の接眼ミクロメーター使用）および膵島 $\mathrm{B}$ 細胞 と考えられている $\mathrm{AF}$ 陽性細胞（1 目0.5mm の接眼 : クロメーター使用）の体積比を計測した。また脳の傷害 部位を確認するため，脳を10\%中性ホルマリンで固定し た後，前頭断切片を作製し，一マトキシリン・エオジン (HE) 染色を行なった。傷害部位が両側の腹内側部以外 の場合は実験対象から除外した。

3. 免疫組織化学的方法: AF-MG 染色切片之連続 する切片を使用し, 一次抗体として $1 / 300$ 倍希釈のモル モット抗ブタインスリン血清（国際試薬）を用い, PAP 法（ヒストセット・ユニバーサルキット，国際試薬）に よって行なった。一次抗体の対照にはモルモット正常血 清を用いて，抗体がラット脺葴に沶いて特異的に免疫交 差反応を示すことを確認した。また免度組織化学的染色 切片に扰いても，抗インスリン陽性細胞すなわち膵島 B 細胞の体積比を求めた（1 目 $0.5 \mathrm{~mm}$ の接眼ミクロメー タ一使用)。

4. 電子顕微鏡的方法：一部の膵臓（脾臓側膵臓）は $2.5 \%$ グルタールアルデヒド（0.1Mカコジナル酸ナトリ

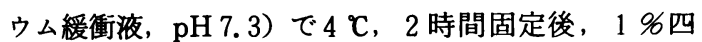
酸化オスミウム (同緩衝液) で $4{ }^{\circ} \mathrm{C}, 2$ 時間後固定し, 常法に従いェポン包埋を行なった。Sorvall Porter Blum 型ウルトラミクロトームで超薄切片作製後, 酢酸 ウラニルとクェン酸㫟の二重染色を施し, 透過型電子顕 微鏡（日立 $\mathrm{H}-300$ 型，75 KV）によって観察を行なった。

\section{成楼}

1. $\mathrm{VMH}$ 破壊肥満ラットの体重および肥満度： $\mathrm{VMH}$ 破壊手術を行なったラット36匹のらち30匹は術後 まるなく死亡したり，あるいは対照よりも悪い成長を示 するのであった。さらに 6 匹は術後しばらくして過食 し，体重や Lee's indexが肥满を示していたが， 1 匹 は脳の前頭断切片の観察から、VMH が片側しか破壊さ れていないことが判明した。よって本実験では 5 匹を肥
Table 1. Body weight, body length and Lee's index of $\mathrm{VMH}$-lesioned obese rats

\begin{tabular}{lccc}
\hline \multicolumn{1}{c}{ Group } & $\begin{array}{c}\text { Body weight } \\
(\mathrm{g})\end{array}$ & $\begin{array}{c}\text { Body length } \\
(\mathrm{cm})\end{array}$ & Lee's index \\
\hline $\begin{array}{l}\text { VMH-lesioned } \\
\text { obesity (5) }\end{array}$ & $385 \pm 15^{\mathrm{a}}$ & $32.2 \pm 0.8^{\mathrm{b}}$ & $0.390 \pm 0.006^{\mathrm{a}}$ \\
$\begin{array}{l}\text { Sham-operated } \\
\text { control (4) }\end{array}$ & $255 \pm 15$ & $38.2 \pm 0.5$ & $0.318 \pm 0.004$ \\
\hline
\end{tabular}

Values are means \pm SEM for the numbers of rats indicated in parentheses.

${ }^{*}$ Lee's index $=\sqrt[3]{\text { Body weight }(\mathrm{g})} /$ Naso-anal length $(\mathrm{cm})$ ${ }^{\text {a }} \mathrm{P}<0.001 \quad{ }^{\text {b }} \mathrm{P}<0.005$

Table 2. Morphometry of the pancreatic islets in $\mathrm{VMH}$-lesioned obese rats

\begin{tabular}{lccc}
\hline \multicolumn{1}{c}{ Group } & $\begin{array}{l}\text { Volume density } \\
\text { of the islets in } \\
\text { pancreas }(\%)\end{array}$ & $\begin{array}{l}\text { No. of } \\
\text { islet } \\
\left(/ \mathrm{mm}^{2}\right)\end{array}$ & $\begin{array}{c}\text { Size of } \\
\mathrm{a} \text { islet } \\
\left(\times 10^{4} \mu \mathrm{m}^{2}\right)\end{array}$ \\
\hline $\begin{array}{l}\text { VMH-lesioned } \\
\text { obesity (5) }\end{array}$ & $3.13 \pm 0.56^{\mathrm{a}}$ & $1.7 \pm 0.2^{\mathrm{a}}$ & $1.86 \pm 0.20^{\mathrm{a}}$ \\
$\begin{array}{l}\text { Sham-operated } \\
\text { control (4) }\end{array}$ & $1.05 \pm 0.06$ & $1.0 \pm 0.1$ & $1.10 \pm 0.08$ \\
\hline
\end{tabular}

Values are means \pm SEM for the numbers of rats indicated in parentheses ${ }^{\text {a }} \mathrm{P}<0.05$

満ラットと判定した。

$\mathrm{VMH}$ 破壊肥満ラットでは術後，3，4 日より対照ラ ットに比べ体重の増加がみられ，しだいにその差が開 き，90日龄の肥満ラットでは385 $\pm 15 \mathrm{~g}$ と対照ラットの $255 \pm 15 \mathrm{~g}$ に比べて有意（ $\mathrm{p}<0.001 ）$ に增加した (Table 1)。体長は肥満ラットで32. $2 \pm 0.8 \mathrm{~cm}$ と対照 ラットの $38.2 \pm 0.5 \mathrm{~cm}$ に比べて有意 $(\mathrm{p}<0.005)$ に短 くなっていた（Table 1)。また肥满度を示す Lee's index は, 肥満ラットで $0.390 \pm 0.006$ と対照ラットの $0.318 \pm 0.004$ よりも有意 $(\mathrm{p}<0.001)$ に大きくなって いた（Table 1)。さらに肥満ラットは対照ラットに比 べて腹腔内，皮下および各種荿器に顕著な脂肪の沈着が 認められた。

2. 光学䫓改鏡的観察: VMH 破壊肥满ラットでは膆 島の著しい肥大やその数の增加が認められ（Fig. 1),

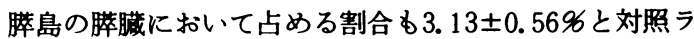

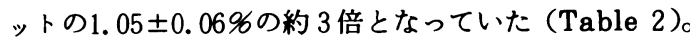
一般にアルデヒド・フクシンはB 細胞の $\beta$ 顆粒を㹸紫色 に染めるとされているが，肥満ラットでは対照ラットに 比へ練胞質の染色性の低い細胞がかなり認められ， $\beta$ 顆 粒の减少が推測された（Fig.1-a，c）。脺島におけ 
Table 3. Morphometry of the AF-positive cells in $\mathrm{VMH}$-lesioned obese rats

\begin{tabular}{lcc}
\hline \multicolumn{1}{c}{ Group } & $\begin{array}{l}\text { Volume density of } \\
\text { AF-positive cells } \\
\text { in islets }(\%)\end{array}$ & $\begin{array}{l}\text { Volume density of } \\
\text { AF-positive cells } \\
\text { in pancreas }(\%)\end{array}$ \\
\hline $\begin{array}{l}\text { VMH-lesioned } \\
\text { obesity (5) }\end{array}$ & $89.1 \pm 1.6^{\mathrm{a}}$ & $2.82 \pm 0.55^{\mathrm{a}}$ \\
$\begin{array}{l}\text { Sham-operated } \\
\text { control (4) }\end{array}$ & $80.7 \pm 1.9$ & $0.85 \pm 0.04$ \\
\hline
\end{tabular}

Values are mean \pm SEM for the numbers of rats indicated in parentheses ${ }^{a} \mathrm{P}<0.05$

る AF 陽性細胞の占める割合は肥満ラットで89.1 $1 \pm 1.6$

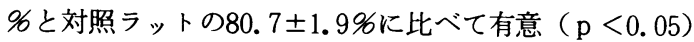
に増加しており，膵缄における $\mathrm{AF}$ 陽性細胞の占める 割合も2.82 $0.55 \%$ と対照ラットの $0.85 \pm 0.04 \%$ の 3 倍 以上となっていた（Table 3 )。

3. 免疫組織化学的検討: VMH 破壊肥満ラットに护 けるB 細胞の抗インスリン血清に対する反応性は，対照 ラットに比べやや低く（Fig. 1-b，d）, AF-MG 染 色標本の場合と同様に顆粒の減少が推測された。しか し，その差は AF-MG 染色ほど顕著ではなかった。B 細胞の膵島に批ける割合は肥満ラットで $90.6 \pm 1.8 \%$ ， 対照ラットで82.2 $2.2 \%$ と AF 陽性細胞の割合よりも 若干多かった（Table 4)。また膵臓における割合も $\mathrm{AF}$ 陽性細胞と同様の結果を示した。

4. 電子顕微鏡的観察：対照ラットのB 細胞の $\beta$ 顆粒 は，限界膜に包まれた電子密度の高い芯をもっており， 限界膜と芯との間吵は比較的大きかった（Fig. 2)。 $\mathrm{VMH}$ 破壊肥満ラットのB細胞に打いて， $\beta$ 顆粒は対照 ラットに比べて電子密度が高かったが，その大きさは 小さく，また数も減少していた（Figs. 4，5）。さらに 細胞によっては電子密度の低い顆粒を多く含むもの (Fig. 3) や, 顆粒の芯が欠如した, 脱顆粒を示す空胞 が存在するもの（Fig. 5) も認められた。肥満ラット のB細胞では不整形を成した核（Figs. 3，4）が対照 ラット（Fig. 2) よりも多く見られた。このような核 において核小体は極めて明瞭なものが多かった（Fig. 4 )。ゴルジ体は肥満ラットにおいてよく発達してお り, 著しく払大した栾状構造は末端部が膨大し，その 中に電子密度の低い物質が含まれていることもあった (Fig. 4 )。また粗面小胞体もよく発達して扣り著しく 肥大していた（Figs. 3，4)。ミトコンドリアはやや 丸く膨化し, クリスタの配列にも乱れが認められ, 数が 增加していた（Figs. 3，4)。
Table 4. Morphometry of the B cells containing insulin in $\mathrm{VMH}$ - lesioned obese rats

\begin{tabular}{lcc}
\hline Group & $\begin{array}{l}\text { Volume density } \\
\text { of B cells } \\
\text { in islets }(\%)\end{array}$ & $\begin{array}{l}\text { Volume density } \\
\text { of B cells } \\
\text { in pancreas }(\%)\end{array}$ \\
\hline $\begin{array}{l}\text { VMH-lesioned } \\
\text { obesity (5) }\end{array}$ & $90.6 \pm 1.8^{\mathrm{a}}$ & $2.85 \pm 0.52^{\mathrm{a}}$ \\
$\begin{array}{l}\text { Sham-operated } \\
\text { control (4) }\end{array}$ & $82.2 \pm 2.2$ & $0.86 \pm 0.04$ \\
\hline
\end{tabular}

Values are means \pm SEM for the numbers of rats indicated in parentheses ${ }^{\text {a }} \mathrm{P}<0.05$

肥満ラットの膵島の他の細胞は, B 細胞で観察された ように顆粒や細胞内小器官の顕著な変化は認められなか った。しかし，膵島周辺部の各細胞に打いて，外分泌の 腺房細胞にみられるチモーゲン顆粒と内分泌顆粒の両方 をもった細胞が， B 細胞だけでなく他の細胞にも対照ラ ットより多く観察された（Fig. 6)。

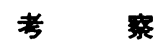

本実験において，VMH 破壊肥満ラットの膵島はその 肥大や数の増加が認められ，体積比が増大することが認 められた。このような膵島の体積比の増大は, 膵島の大部 分を占める $\mathrm{B}$ 細胞の体積比の增大が原因と考えられる。 肥満ラットの膵島周辺部に内分泌顆粒と外分泌顆粒をも った細胞が観察されたが，このような細胞は acinarislet cell[14], mixed cell あるいは intermediate cell $[15 ， 16]$ などと表現され, 膵島の肥大過程におけ る外分泌細胞の膵島内分泌細胞への転換の可能性を示唆 すると報告されている。このことから，肥満ラットでこ のよらな移行細胞が多いことは, 外分泌細胞の内分泌細 胞の移行が促進されているものと推察される。

肥満ラットの膵島 B 細胞においてかなり観察された脱 顆粒像は, 遺伝性肥満の Zukker ラット (fa/fa) [17], 肥満型糖尿病の yellow KK マウス [16]，アロクサン 給与ラット [18], トルブタミド投与ラット [19], コル チゾン投与ウサギ［20］やピロカルピン投与イ 邓 [21] などでも認められており，顆粒分泌の充進の表現像と考 えられる。肥満ラットでやや多く見られた不整形の核 は，表面積を増加させることて機能的要求に対処してい ることを示しているものと考えられ，その細胞が非常に 活発に機能していると推察される。また, ゴルジ体や粗 面小胞体の発達は Zukker ラット [17], sand ラット [22], 糖尿病チャイニーズ・八ムスター [23] やピロカ 
ルピソ投与イヌ $[21]$ などにも認められており， $\beta$ 顆粒 の合成や眝蔵が進んでいることを示している。ミトコン ドリアの数の増加や変形は, yellow $\mathrm{KK}$ マウス [16] や糖尿病ミュータント・マウス (C57 BL/Ks-db/db) [24］と同様に, 細胞機能の亢進に伴う変化の一つと考 えられる。

以上の成績から、 VMH 破壊肥満ラットの膵島および 膵島 $\mathrm{B}$ 細胞の体積比の増大や $\mathrm{B}$ 細胞の機能元進は, イン スリンの合成および分泌が盛んであることを示してお り, $\mathrm{VMH}$ 破壊肥満ラットにおける脂肪合成促進の成因 と推測される。ヒトに拈ける肥満の原因として，体内の 脂肪の蓄積があげられているが，VMH 破壊肥満ラット においても体内に多量の脂肪が蓄積されるので, その成 因である高インスリン血症の機序を明らかにするための モデル動物として重要と思われる。

$\mathrm{VMH}$ 破壊による膵島への影響はB 細胞に対してだけ でなく, 他の膵島細胞に対しても認められる。Seino et al. [25] の単離愺蔵の灌流実験によるインスリンだけ でなくソマトスタチンの分泌の増加が認められており, ソマトスタチンを分泌するD細胞の形態的変化も予想さ れる。また, 膵臓ポリペプチドについてはほとんど検討 されていない。今後はさらに、グルカゴン、ソマトスタ チン, 愺蔵ポリペプチドなどの他の膵蔵ホルモンを分泌 するA，Dおよび PP [26] 細胞の同定を行ない， B 細 胞との相互関係を形態学的に検討し, 肥満との関連性に ついて調べる必要がある。

\section{要約}

視床下部腹内側核 $(\mathrm{VMH})$ 破壊動物は肥満を示すこ とから, 肥満モデル動物として利用されているが，今 回, 電気破壊により $\mathrm{VMH}$ を破壊して作製した肥満ラ ットの脺島 B 細胞の形態変化について観察した。肥満ラ ットは対照ラットに比べ体重が重くなるが, 体長は短く なり，体内に著しい脂肪の蓄積が認められるようになる とともに, 膵島および膵島 $\mathrm{B}$ 細胞は体積比も有意に大き くなった。また肥満ラットのB細胞には，アルデヒド・ フクシンに対する染色性や抗インスリンに対する反応性 の低下したものが多く見られた。電顕観察によると，B 細胞には $\beta$ 顆粒の著しい分泌を示す脱顆粒像が見られ， インスリン分泌の增大が推測された。さらにゴルジ体や 粗面小胞体の発達などから, 顆粒合成の亢進も推測され た。以上の成績から，VMH 破壊による肥満ラットにお いては，愺蔵でのインスリンの合成や分泌が増大すると ともに, 脂肪の合成が促進されているものと推察された。

\section{文献}

[1] Hetherington, A. W. and Ranson, S. W. (1942). The spontaneous activity and food intake of rats with hypothalamic lesions. Am J. Thysiol, 136, 609-617.

[2] Hales, C. N and Kennedy, G. C. (1964). Plasma glucose, non-esterified fatty acid and insulin concentrations in hypothalamic-hyperphagic rats. Biochem J., 90, 620-624.

［3］井上修二 (1979)。串験肥满モデル。実験肥满動物の内 分泌的異常と成因. ホルモンと臨床，27，601-608.

[4] Inoue, S., Campfield, L. A., and Bray, G. A. (1977). Comparison of metabolic alternations in hypothalamic and high fat diet-induced obesity Am J. Physiol, 233, R 162-R 168.

[5] Frohman, L. A. and Bernardis, L. L. (1968). Growth hormone and insulin levels in weanling rats with ventromedial hypothalamic lesions. Endocrinology, 82, 1125-1132.

[6] Kennedy, G. C. and Parker, R. A. (1963). The islets of Langerhans in rats with hypothalamic obesity. Lancet, II, 981-982.

[7] Han, P. W., Yu, Y.-K., and Chow, S. L. (1970). Enlarged pancreatic islets of tube-fed hypophysectomized rats bearing hypothalamic lesions. Am J. Physiol, 218, 769-771.

［8］石橋武彦・宮本 元・佐藤英明 (1977)，視床下部性の 肥満ネズミに拈ける脺荿ランゲルハンス島の組織学的観 察. 医学と生物学, 94, 93-96.

［9］和泉英彦（1978）。視床下部性肥満ラットの膆ラ氏島の 組織学的検討. 日内分泌会誌， 54，876-890。

[10] 安岡 劭 (1966). 視床下部傷害による脳の組織学的研 究. 四国医学雑誌, 22, 231-245.

[11] Lee, M. O. (1929). Determinations of surface area of the white rat with its application to the expression of metabolic results. Am J. Thysiol, 89, 24-33.

[12］宮本 元・三笠牧子・石橋武彦 (1989). ブタおよびイ ノブタ膵荿におけるランゲルハンス島とB細胞の分布. 日畜会報，60，255-259.

[13] Weibel, E. R., Kistler, G. S., and Scherle, W. F. (1966). Practical stereological methods for morphometric cytology. J. Cell Biol, 30, 23-38.

[14] Mikami, S. and Mutoh, G. S. (1971). Light-and electron-microscopic studies of the pancreatic islet cells in the chicken under normal and experimental conditions. Z Zelforsch, 116, 205-227.

[15] Pictet, R., Orci, L., Gonet, A. E., Rouiller, C., and Renold, A. E. (1967). Ultrastructural studies of the hyperplastic islets of Langerhans of spiny mice (Acomys Cahirinus) before and during the development of hyperglycemia. Diabetologia 3, 188 -211 .

[16] Shino, A. and Iwatsuka, H. (1970). Morphological observations on panceratic islets of spotaneous diabetic mice, "Yellow KK". Endocrinol Jap., 17, 459-476.

[17] Shino, A., Matsuo, T., Iwatsuka, H., and Suzuki, Z. (1973). Structural changes of pancreatic islets in genetically obese rats. Dabetologia, 9, 413-421.

[18］ 小林 寛・高橋嘉幸・城下 尚（1964）。アロクサン給 与と下垂体剔除がラット縢荿の LANGERHANS 氏島に 及ぼす影響。日本組織学記録, 25，199-216。

[19] Williamson, J. R., Lacy, P. E., and Grisham, J W. (1961). Ultrastructural changes in islets of the rat 
produced by tolbutamide. Diabetes, 10, 460-469.

[20] Volk, B. W. and Lazarus, S. S. (1963). Ulatramicroscopic studies of rabbit pancreas during cortisone treatment. Diabetes 12, 162-173.

[21] 渡 仲三 (1959).シンポジゥム【インスリン分泌の機 構と調節. 2. 2，3 の丰験条件下における膵島の超微形 態学, 特に $\mathrm{B}$ 紐胞の変化について. 日内分泌会誌，44, 721-727.

[22] Like, A. A. and Miki, E. (1967). Diabetic syndrome in sand rats. IV. Morphologic changes in islet tissue. Diabetologia, 3, 143-166.

[23] Like, A. A, Gerritsen, G. C., Dulin, W. E., and Gaudreau, P. (1974). Studies in the diabetic Chinese hamster : Electron microscopy of pancreatic islets. Dabetologia, 10, 509-520.
[24] Like, A. A. and Chick, W. L. (1970). Studies in the diabetic mutant mouse : II. Electron microscopy of pancreatic islets. Diabetologia, 6, 216-242.

[25] Seino, Y., Seino, S., Takemura, J., Tsuda, K., Nishi, S., Ishida, H., Seno, M., Usami, M., Ikeda, M., and Imura, H. (1984). Changes in insulin, somatostatin, and glucagon secretion during the development of obesity in ventromedial hypothalamic-lesioned rats. Endocrinology, 114, 457-461.

[26] Kaung, H.-L. C. (1985). Electron microscopic immunocytochemical localization of glucagon and pancreatic polypeptide in rat pancreas: Characterization of a population of islet cells containing both peptides. Anat. Rec., 212, 292-300.

\section{Explanation of Figures}

Fig. 1. Light micrographs of the pancreatic islets of obese rat $(a, b)$ and control rat $(c, d)$. The hypertrophy of the islets and the degranulation showed by the slight reactions of the B cells are observed in obese rat. Aldehyde fuchsin-Masson Goldner staining (a, c) and immunohistochemistry for insulin $(\mathrm{b}, \mathrm{d}) \times 300$

Fig. 2. Electron micrograph of the B cell of control rat. Nucleus (N) shows round shape. $\times 4000$

Fig. 3. Electron micrograph of the B cell of obese rat. Pale granules are numerous. Nucleus (N) shows irregular shape. Mitochondria (arrowheads) swelled and are round-shaped. $\times 4000$
Fig. 4. Electron micrograph of the B cells of obese rat. Irregular nucleus $(\mathrm{N})$ is often observed. Golgi apparatus (GA) and rough endoplasmic reticulum were well developed. Mitochondria (arrowheads) swelled and are round-shaped. $\times 4000$

Fig. 5. Electron micrograph of the $B$ cell of obese rat. A size of a granule is mostly a little smaller, and some cores of granules are more electron-dense. Degranulation are remarkable. $\times 16000$

Fig. 6. Electron micrograph of the islet of obese rat. A number of mixed cells (MC) containing both endocrine and exocrine granules are observed along the periphery of the islet. $\times 2000$ 

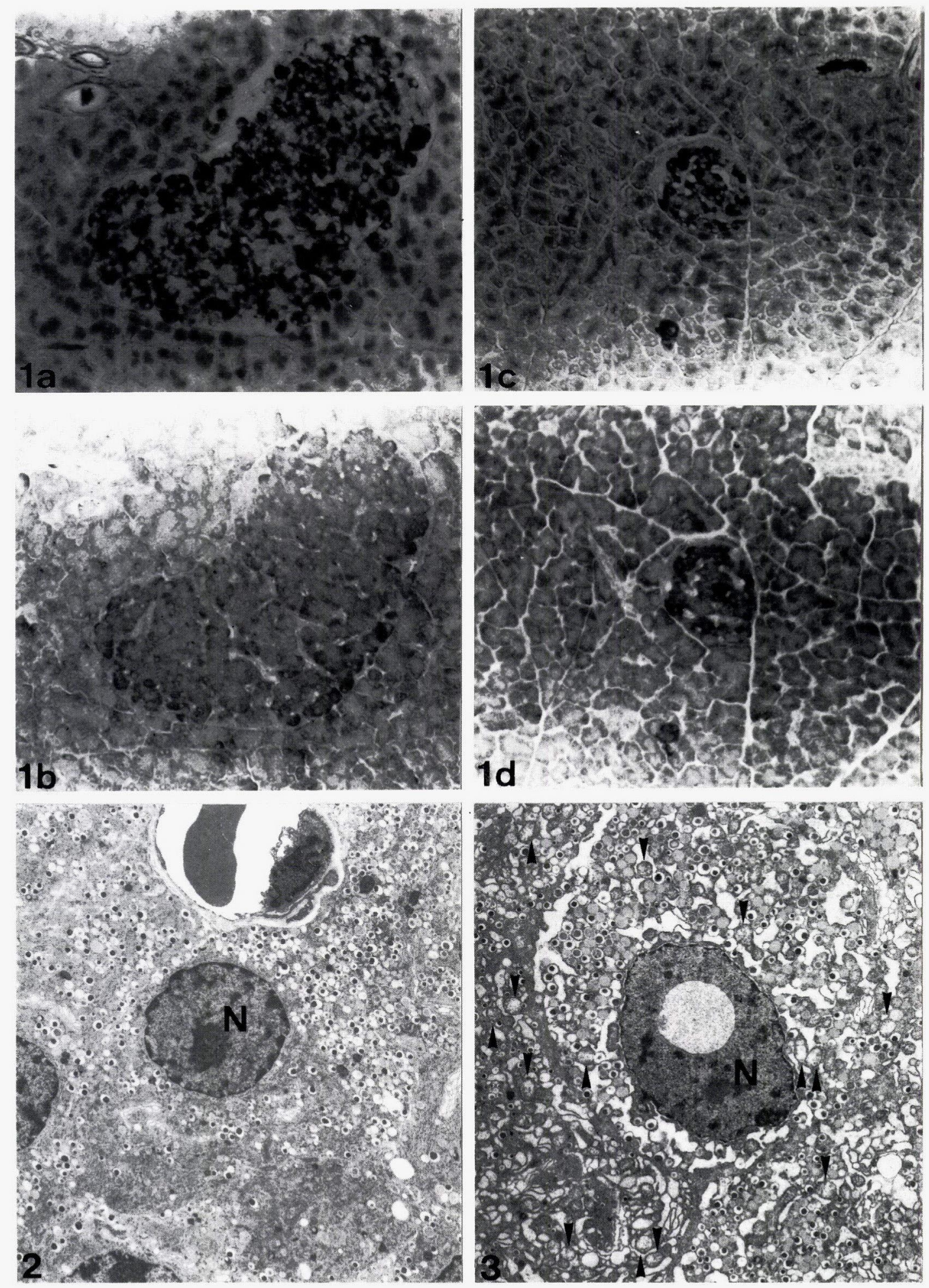


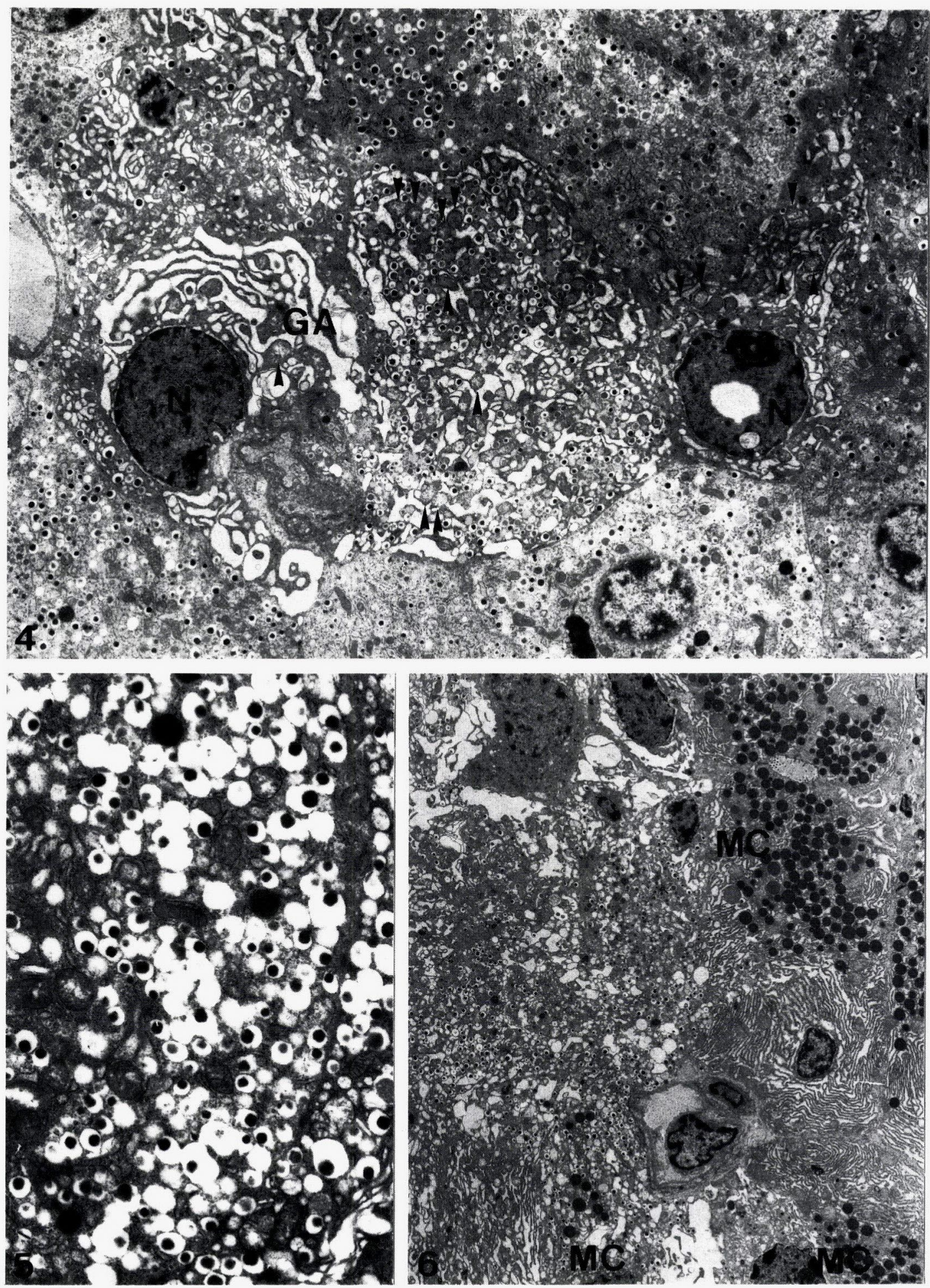

